\title{
FAK/PYK2 inhibitors defactinib and VS-4718 enhance immune checkpoint inhibitor efficacy
}

\author{
Jennifer Ring, Yajuan Li, Irina Shapiro, Yan Wang, David Weaver, Jonathan Pachter \\ From 30th Annual Meeting and Associated Programs of the Society for Immunotherapy of Cancer (SITC 2015) \\ National Harbor, MD, USA. 4-8 November 2015
}

Although durable responses to single agent immune checkpoint inhibitors have been reported, additional approaches are needed to extend this therapeutic benefit to a greater proportion of cancer patients. Accordingly, substantial efforts are ongoing to identify agents that can augment $\mathrm{T}$ cell-mediated killing of tumor cells and potentiate the effects of checkpoint inhibitors. Focal Adhesion Kinase (FAK) and the closely related family member PYK2 are potentially valuable targets in this regard due to the roles of these protein kinases in regulating key cellular populations in the tumor microenvironment. In addition to the potency of the small molecule FAK/PYK2 inhibitors defactinib (VS-6063) and VS-4718 to target cancer stem cells, we have also reported that these agents inhibited monocyte-derived macrophages, decreased IL-6 production from macrophages in vitro, and reduced tumor-associated macrophages in xenograft models.

We now report that defactinib and VS-4718 stimulate proliferation of $\mathrm{CD} 8+$ cytotoxic $\mathrm{T}$ cells. This is in distinct contrast to other protein kinase inhibitors, such as the SRC inhibitor dasatinib and the MEK inhibitor trametinib, which potently impair the proliferation of CD8+ cytotoxic $\mathrm{T}$ cells. Using primary human CD8+ T cells isolated from healthy donors, both FAK/PYK2 inhibitors dose-dependently increased proliferation of $\mathrm{CD} 8+\mathrm{T}$ cells in the presence of anti-CD3/anti-CD28 coated beads.

Based on the observed enhancement of CD8+ T cells and previously noted inhibition of tumor-associated macrophages, we investigated whether FAK/PYK2 inhibitors potentiate the anti-tumor efficacy of an anti-PD-1 monoclonal antibody in syngeneic mouse tumor models. Mice bearing established MC38 colorectal tumors were treated with VS-4718 in combination with an anti-PD-1 antibody. Combination of VS- 4718 with anti-PD-1 extended the median overall survival to 42 days relative

Verastem Inc., Needham, MA, USA

(c) 2015 Ring et al. This is an Open Access article distributed under the terms of the Creative Commons Attribution License (http:// creativecommons.org/licenses/by/4.0), which permits unrestricted use, distribution, and reproduction in any medium, provided the original work is properly cited. The Creative Commons Public Domain Dedication waiver (http://creativecommons.org/publicdomain/ zero/1.0/) applies to the data made available in this article, unless otherwise stated. to 21,25 and 28 day median overall survival with vehicle control, single agent anti-PD-1 and single agent VS4718 , respectively. Moreover, on day $56,30 \%$ of mice treated with the VS-4718/anti-PD-1 combination were alive in contrast to the vehicle control, single agent VS4718 , and single agent anti-PD-1 groups in which no mice survived. Studies are currently underway to better understand the immune cell changes in these tumors following VS-4718 and anti-PD-1 combination therapy.

These data provide a rationale for clinical trials in cancer patients to test whether a FAK/PYK2 inhibitor in combination with an immune checkpoint inhibitor could increase the breadth of responsive tumor types, increase the number of responders, and confer a more durable anti-tumor response.

Published: 4 November 2015

doi:10.1186/2051-1426-3-S2-P354

Cite this article as: Ring et al:: FAK/PYK2 inhibitors defactinib and VS4718 enhance immune checkpoint inhibitor efficacy. Journal for ImmunoTherapy of Cancer 2015 3(Suppl 2):P354.

Submit your next manuscript to BioMed Central and take full advantage of:

- Convenient online submission

- Thorough peer review

- No space constraints or color figure charges

- Immediate publication on acceptance

- Inclusion in PubMed, CAS, Scopus and Google Scholar

- Research which is freely available for redistribution 